\title{
Examination of Correlation Between Lead and Histidine in Eleagnus angustifolia L., Vitis vinifera L., and Nerium oleander L. Using ICP-MS and HPLC-MS
}

\author{
Sukran Akkus Ozen and Mehmet Yaman* \\ Firat University, Faculty of Science, Department of Chemistry, Elazig, Turkey
}

\section{INTRODUCTION}

Over the past two centuries, anthropogenic and industrial activities have led to high emission of toxic metals into the environment at high concentrations. Because metals emitted into the environment are toxic and non-biodegradable (unlike organic compounds), the removal of excess metal ions from polluted sites is important. Lead is utilized in many industrial activities and is considered a major contaminant in most industrial factories. Lead, as with most of the heavy metals, can be harmful to humans and animals and tends to bioaccumulate through the food chain (1-4). Thus, numerous efforts have been undertaken to find methods for removing heavy metals from soil. Among those methods, conventional (excavation), chemical remediation, phytoremediation, soil washing, nano materials and remediation with bacteria are used (5-7). The excavation method is neither economical nor practical. Because chemical remediation methods involve the use of chemicals, this method is not in universal use, is very costly and may cause secondary pollution (8).

Phytoextraction (in other words, phytoremediation) is the removal of metals from soil using hyperaccumulator plants. Phytoextraction or phytoremediation is 1000 -fold less costly than conventional remediation methods and is also environmentally friendly (8-9). The use of hyperaccumulator plants opens a new branch of phytoremediation technology that is scientific in its approach to remove, extract, or

*Corresponding autbors

ijpacmy@gmail.com

\begin{abstract}
In this study, ICP-MS and HPLC-MS methods were used for the determination of lead and histidine, respectively, in the leaves of the plant species Eleagnus angustifolia L., Vitis vinifera $L$. and Nerium olean$\operatorname{der} L$., sampled at industrial areas, including the cities of Gaziantep and Bursa, Turkey. In the determination of histidine by HPLC-MS, all of the system parameters such as flow rate of the mobile phase, fragmentation potential, injection volume and column temperature were optimized and found to be 0.2

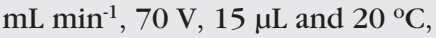
respectively. Histidine was extracted from the plant sample by ultrapure water at $90{ }^{\circ} \mathrm{C}$ for 30 minutes.

The concentrations of histidine were found to be in the range of 3-23 mg kg-1 for Eleagnus angustifolia L., 2-33 $\mathrm{mg} \mathrm{kg}^{-1}$ for Vitis inifera $L$., and 3-11 $\mathrm{mg} \mathrm{kg}^{-1}$ for Nerium oleander $L$. The concentrations of $\mathrm{Pb}$ were in the range of $1-45 \mathrm{mg} \mathrm{kg}^{-1}$ for Eleagnus angustifolia L., 1-32 $\mathrm{mg} \mathrm{kg}^{-1}$ for Vitis vinifera $L$. and 1-53 $\mathrm{mg} \mathrm{kg}^{-1}$ for Nerium olean$\operatorname{der} L$. A linear correlation between $\mathrm{Pb}$ and histidine for Eleagnus angustifolia $L$. at $\mathrm{r}=0.77$ was found.
\end{abstract}

inactivate metal ions in the soil using plants $(5,10-11)$. In phytoremediation, the basic concept is as follows: Growing and harvesting of plants in the polluted soils, burning of plants and smelting or storing of the ash. Hyperaccumulators often exhibit higher metal concentrations in their tissues than are present in the soil and can tolerate high metal concentrations without symptoms of toxicity (12).
Plant ligands play a role in the sequestration of metals from soils, transport to the above-ground tissue, and finally storage (13). Nitrogen-donor ligands, and especially free amino acids including histidine and cysteine, organic acids, metallothioneins and phytochelatins, are assumed to play a role in hyperaccumulators (10-14). While there are many metal-binding biomolecules, this study focuses only on the histidine ligand which plays a role in sequestering, transporting or storing of the accumulated metal, and serves as a tridentate ligand via its carboxylato, amine, and imadazole functions. As a result, future discovery of new hyperaccumulator plants is of great importance. In terms of the known toxicity of elements, most concern to date has been focused on $\mathrm{Cu}, \mathrm{Cd}, \mathrm{Pb}$, and $\mathrm{Ni}$ found in plants (15-20).

The aim of this study was, first, to examine the correlation between $\mathrm{Pb}$ and histidine in plant leaves, such as Eleagnus angustifolia L., Vitis vinifera L., and Nerium oleander $L$. Second, to establish the extent of $\mathrm{Pb}$ pollution in two industrialized cities in Turkey, namely Gaziantep and Bursa, using these three plant species. For this purpose, the ICP-MS and HPLC-MS techniques were applied. The representative locations were industrial zones, including an obsolete lead battery production site, a cement factory, and other industrial factories found within these cities.

\section{EXPERIMENTAL}

\section{Instrumentation and Reagents}

The concentrations of $\mathrm{Pb}$ were determined using a PerkinElmer ${ }^{\circledR}$ ELAN® ${ }^{\circledR} 9000$ inductively coupled plasma mass spectrometer (ICP-MS) 
(PerkinElmer, Inc., Shelton, CT, USA). The ICP-MS operating conditions were taken from the manual handbook and are listed in Table I. A CEM MARS-X-press microwave digestion system (CEM Corporation, USA) was used to digest the samples before analysis. Ultrapure water, obtained with a Direct-Q ${ }^{\circledR}$ water purification system (Millipore Corporation, USA) was used for the preparation of all samples and standards.

An Agilent 1200 HPLC-MS system was used for the determination of histidine (Agilent Technologies, USA). The instrument was equipped with an autosampler, a binary pump, a temperature-controlled column oven, and an Agilent 6110 MS detector, which was operated in the selected ion monitoring and scan mode equipped with positive ion electrospray ionization. The HPLC effluent entered the mass spectrometer through an electrospray capillary at $3000 \mathrm{~V}$. Nitrogen was used as the drying and vaporizer gas at 300 and $500{ }^{\circ} \mathrm{C}$, respectively. The drying gas flow rate was 11.0 L min $^{-1}$ (Table I). An Agilent Zorbax Eclipse XDB-C18 column $(4.6 \mathrm{~mm}, 150 \mathrm{~mm}$, and $5 \mu \mathrm{m}$ particle sizes) was used. Unless otherwise stated, all chemicals used throughout the study were of highpurity reagent grade. Concentrated nitric acid (65\%, Merck, Germany) was used in the digestion procedure. The lead stock solution (1000 $\mathrm{mg} \mathrm{L}^{-1}$ ) was prepared from its nitrate salt (Merck).

\section{Sampling and Sample Preparation}

Eleagnus angustifolia L., Vitis vinifera $L$. and Nerium oleander $L$. leaves were collected in Gaziantep and Bursa, cities with populations of 1,500,000 and 2,000,000, located in SE and NW Turkey, respectively,

TABLE I

Operating Conditions for Histidine and $\mathbf{P b}$ Determination by HPLC-MS and ICP-MS

\begin{tabular}{|c|c|}
\hline \multicolumn{2}{|l|}{ HPLC-MS Conditions } \\
\hline Mobile phase & Formic acid $10 \%$, acetonitrile $90 \%$ \\
\hline Mobile phase flow rate & $0.2 \mathrm{~mL} \mathrm{~min}^{-1}$ \\
\hline Column & Zorbax XDB-C $18(4.6 \mathrm{~mm} \times 150 \mathrm{~mm}, 5 \mu \mathrm{m})$ \\
\hline Column temperature & $20^{\circ} \mathrm{C}$ \\
\hline Fragmentor potential & $70 \mathrm{~V}$ \\
\hline Injection volume & $15 \mu \mathrm{L}$ \\
\hline Nebulizer pressure & 30 psi \\
\hline Drying gas flow & 11.0 $\mathrm{L} \mathrm{min}^{-1}$ \\
\hline Drying gas temperature & $300^{\circ} \mathrm{C}$ \\
\hline Vaporizer temperature & $500{ }^{\circ} \mathrm{C}$ \\
\hline Capillary voltage & $3000 \mathrm{~V}$ \\
\hline \multicolumn{2}{|l|}{ ICP-MS Conditions } \\
\hline Plasma gas flow rate & $15 \mathrm{~L} \mathrm{~min}^{-1}$ \\
\hline Carrier gas flow rate & $0.9 \mathrm{~L} \mathrm{~min}^{-1}$ \\
\hline Sample uptake rate & $1.0 \mathrm{~L} \mathrm{~min}^{-1}$ \\
\hline Nebulizer & Cross flow \\
\hline Spray chamber & Ryton ${ }^{\circledR}$, Double pass \\
\hline Sample uptake rate & $1.0 \mathrm{~mL} \mathrm{~min}-1$ \\
\hline Plasma power (RF power) & $1000 \mathrm{~W}$ \\
\hline
\end{tabular}

\section{Atomic Spectroscopy \\ $\bigcirc$ Vol. 37(4), July/August 2016}

with important industrial centers (see Figure 1). The locations of the plant samplings were also obtained by modification from Google Map. The control samples were collected away from urban and industrial areas in the summer of 2011. About $100 \mathrm{~g}$ of healthy, fresh leaves were taken from each site. The leaves were transferred to the laboratory in plastic bags, washed with tap water, and rinsed with ultrapure water. After drying at $70{ }^{\circ} \mathrm{C}$, the samples were ground using an agate mortar and then homogenized.

\section{ICP-MS Analysis}

In the digestion step, a $0.3 \mathrm{~g}$ sample was transferred to a Teflon ${ }^{\circledR}$ vessel and $5.0 \mathrm{~mL}$ of concentrated nitric acid added. Then, the mixture was irradiated at $1600 \mathrm{~W}$ (80\% power) and $200{ }^{\circ} \mathrm{C}$ for 15 minutes and at $1600 \mathrm{~W}(50 \%$ power) and $170{ }^{\circ} \mathrm{C}$ for 15 minutes in accordance with the instructions provided in the microwave oven manual. The cooled solution was heated until near dryness. After addition of $20 \mathrm{~mL}$ of $0.1 \mathrm{M}$ nitric acid, the solution was filtered, if necessary (a precaution due to the high sensitivity of the ICP-MS with the particles), and the clear solution was analyzed for Pb by ICP-MS. Each sample was analyzed in triplicate.

\section{HPLC-MS Analysis}

The HPLC-MS method was optimized for the determination of histidine in Eleagnus angustifolia L., Vitis vinifera L., and Nerium oleander $L$. leaves considering the peak area, peak symmetry, and abundance. A suitable mobile phase was investigated, and the best results were obtained using a binary gradient elution of $10 \%$ formic acid (mobile phase $A$ ) and 90\% acetonitrile (mobile phase $\mathrm{B}$ ). The flow rate of the mobile phase, fragmentor potential, injection volume, and column temperature 
were optimized at values of $0.2 \mathrm{~mL} \mathrm{~min}^{-1}, 70 \mathrm{~V}, 15 \mu \mathrm{L}$ and $20{ }^{\circ} \mathrm{C}$, respectively. To extract histidine from $1.5 \mathrm{~g}$ of plant leaves, the following steps were taken: $0.10 \mathrm{M}$ $\mathrm{HCl}$ and ultrapure water were heated from 20 to $90{ }^{\circ} \mathrm{C}$ and stirred from 15 to 60 minutes. The optimum conditions were found to be ultrapure water at $90{ }^{\circ} \mathrm{C}$ and a stirring time of 30 minutes. The volume of ultrapure water was optimized using a constant mass of plant material; the best results were obtained with $30 \mathrm{~mL}$. To determine the best derivatization reagent, direct ultrapure water (underivatization), fenil isothio- siyanat and dabsyl chloride were examined by using the scheme listed in Table II.

One-way analyses of variance (ANOVA) were conducted to test the equality of the mean values for each plant species of interest. One of the pairwise ANOVA comparison tests, the Tukey HSD, was carried out to find which of the plant means is different from each other depending on location. The IBM ${ }^{\circledR}$ SPSS (version 15, SPSS Inc., IL, USA) statistical program was used for all statistical computations. Statistical significance was considered when $\mathrm{P}$ was equal to or higher than 0.05 .

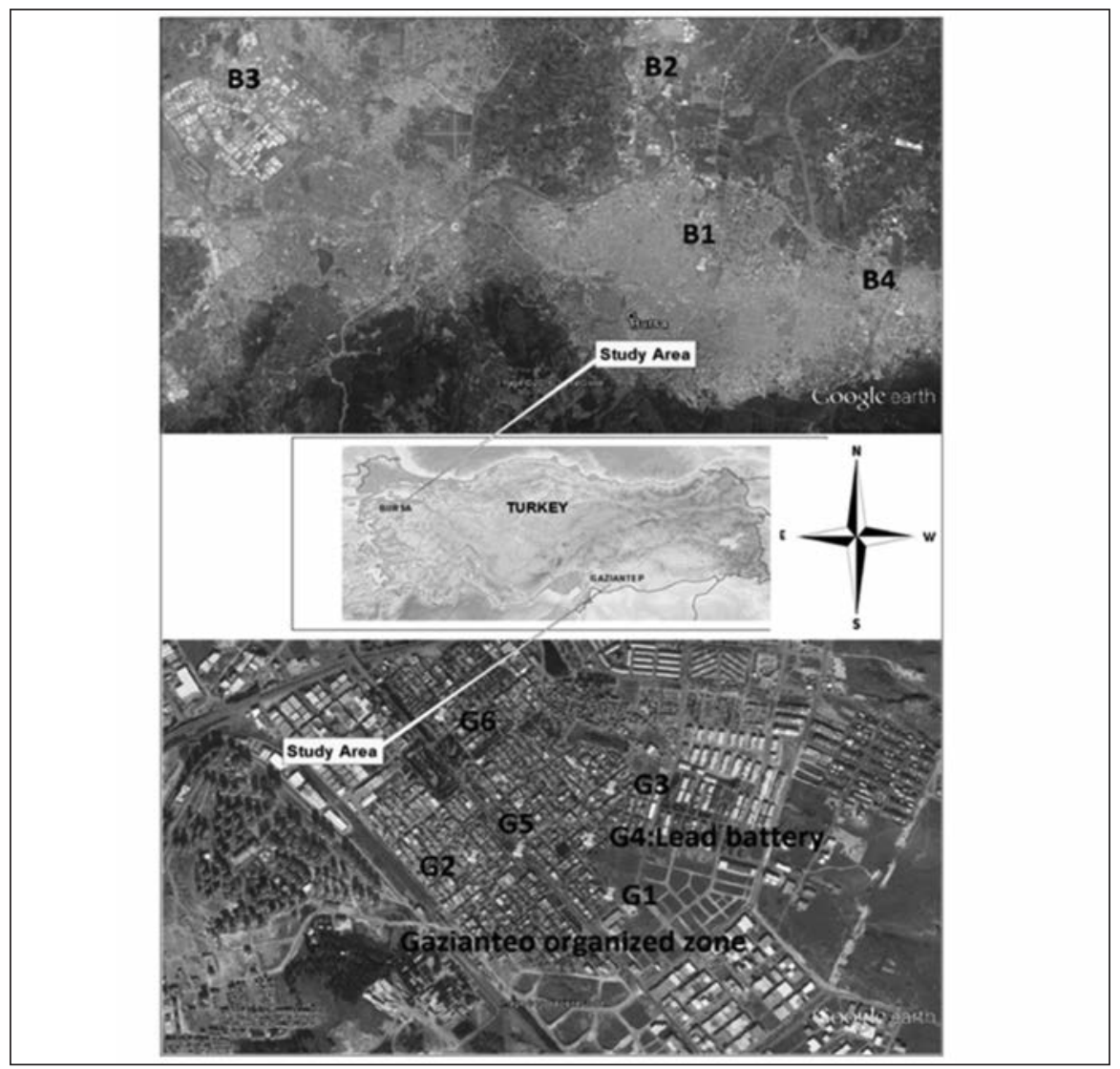

Fig. 1. Map of sampling locations. (a) B1: Bursa organized industrial zone, in city center; B2: Bursa city, Demirtas organized industrial zone; B3: Bursa city, Nilufer organized industrial zone; B4: Bursa city, Gursu organized industrial zone. G4: Around the obsolte lead battery center, distance 50 m; G1: Gaziantep city, 200 meters South direction away from G4); G2: Gaziantep city, 400 meters West direction away from G4; G3: Gaziantep city, 200 meters North direction away from G4; G5: Gaziantep city, 200 meters West direction away from G4; G6: Gaziantep city, 1000 meters Northwest direction away from $G 4$.

\section{RESULTS AND DISCUSSION}

\section{Analytical Performance}

There are three methods to check the accuracy of the results obtained: (a) the use of Standard Reference Material (SRM), (b) comparison of the results with those obtained by independent methods for the same samples, and (c) the spike recovery test. In this study, the first method was used for the $\mathrm{Pb}$ determinations by ICP-MS and the third method was used for the histidine determination by HPLCMS. The obtained concentration of $\mathrm{Pb}$ in SRM NCS DC73348 Bush Branches and Leaves - Trace Elements (China National Analysis Center for Iron and Steel, Beijing, P.R. China) was found to be 6.8 $\mu \mathrm{g} \mathrm{g}^{-1}$ which is close to the certified value of $7.1 \mu \mathrm{g} \mathrm{g}^{-1}$. Because a recovery of $96 \%$ was achieved, the $\mathrm{Pb}$ determination in this study was considered to be accurate.

In the HPLC-MS determination for histidine, the recoveries from the plant leaves fortified with $3 \mathrm{mg}$ $\mathrm{kg}^{-1}$ of histidine were employed to check for accuracy. A recovery of 96\% was obtained. The effects of contamination were eliminated by subtracting the blank levels from the obtained values.

\section{LOD and LOQ Determination for Histidine and $\mathbf{P b}$}

There are three ways of determining the limits of detection (LOD) and the limits of quantitation (LOQ): (a) based on visual evaluation, (b) based on the signal-tonoise ratio, (c) based on standard deviation of the response and slope. In this study, the third way was applied by using $3 x$ the standard deviation of the low concentration/slope of the calibration line for the LOD and 10x the standard deviation of the low concentration/ slope of the calibration line for the LOQ. The limits of detection and quantitation for histidine were found to be $0.025 \mathrm{mg} \mathrm{L}^{-1}$ and 0.075 
$\mathrm{mg} \mathrm{L}^{-1}$, respectively. The linear dynamic range using histidine standards extended from 0.075 to 5.0 $\mathrm{mg} \mathrm{L}^{-1}$ using the optimized conditions with a correlation coefficient of 0.9999. Using ICP-MS, the LOD and LOQ for $\mathrm{Pb}$ were found to be 0.1 and $1 \mathrm{ng} \mathrm{L^{-1 }}$, respectively. Related to the derivatization reagent, it was found that dabsyl chloride is the best reagent.

The concentrations of $\mathrm{Pb}$ were found to be in the range of 1-45 $\mathrm{mg} \mathrm{kg}^{-1}$ for Eleagnus angustifolia L., 1-32 $\mathrm{mg} \mathrm{kg}^{-1}$ for Vitis vinifera L., and 1-53 mg kg-1 for Nerium oleander $L$. The concentrations of histidine were found to be in the range of 3-23 mg kg-1 for Eleagnus angustifolia L., $2-33 \mathrm{mg} \mathrm{kg}^{-1}$ for Vitis vinifera $L$. , and $3-11 \mathrm{mg} \mathrm{kg}^{-1}$ for Nerium oleander $L$.

Kabata-Pendias (2011) (21) considered the $\mathrm{Pb}$ concentrations in plants at a value lower than $10 \mathrm{mg}$ $\mathrm{kg}^{-1}$ as normal or acceptable, while Allen (1989) (22) considered the much lower value of $3 \mathrm{mg} \mathrm{kg}^{-1} \mathrm{~Pb}$. Kabata-Pendias (21) also considered $30 \mathrm{mg} \mathrm{kg}^{-1}$ of $\mathrm{Pb}$ as an excessive or toxic level, and reported that 43 $\mathrm{mg} \mathrm{kg}^{-1}$ of $\mathrm{Pb}$ is the threshold value causing death to trees.

Hyperaccumulation has been recognized as an extreme physiological response in heavy metal tolerance. In other words, hyperaccumulator plants can tolerate much higher metal concentrations without symptoms of toxicity (12, 23-25). However, the physiological processes involved in hyperaccumulation are not well understood. Plants must be able to store the metal ions in nonlabile complexes to eliminate toxic effects. The most likely areas for storage are the cell wall, the cytosol, and the vacuole. A number of steps are required for metal ions to reach the storage tissues: mobilization and uptake from soil, compartmentation and sequestration within roots, transfer to the xylem for transport, sequestration and storage in leaf cells (26). It must also be noted that the distribution between metals changes in above-ground tissue and each stage the accumulation of metals. The hyperaccumulator may be detoxifying the metal in the leaves via strong binding ligands. Thus, the

Table II Analytical Steps for Histidine Determination

\footnotetext{
* Sample (1.5 g)

* Distilled water added $(30 \mathrm{~mL})$

* Mixed at $90^{\circ} \mathrm{C}$ for $30 \mathrm{~min}$

* Filtered

* Dried at room temperature. for $24 \mathrm{~h}$

* $\mathrm{HCl}$ added $(5 \mathrm{~mL}$ of $0.1 \mathrm{M})$

* Placed in vortex mixer

* Reaction buffer (sodium hydrogen carbonate $0.15 \mathrm{M}, \mathrm{pH} 8.6$ )

* Placed in vortex mixer

* Placed in a water bath at $70{ }^{\circ} \mathrm{C}$ for $15 \mathrm{~min}$

* Added - $8 \mathrm{~mL}$ dilution buffer (mixture of $50 \mathrm{~mL}$ acetonitrile $+25 \mathrm{~mL}$ ethanol $+25 \mathrm{~mL}$ sodium dihydrogenphosphate, $9 \mathrm{mM}$ dimethylformamide $4 \%$ and triethylamine $0.15 \%$ [pH 6.55 with phosphoric acid])

* Centrifugation at 10,000 rpm for $10 \mathrm{~min}$

* Filtered through $(0.45 \mu \mathrm{m})$ nylon membrane

* Analysis with HPLC-MS
}

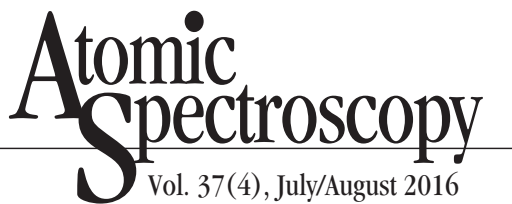

ligand including histidine, cysteine, and phytate may play a part in the sequestration within isolated compartments (10-14).

Kaya et al. $(15,19-20)$ reported that $\mathrm{Pb}$ concentrations in Eleagnus angustifolia L., Vitis vinifera L., and Nerium oleander L. leaves growing in areas around a lead battery factory were up to $2750 \mathrm{mg}$ $\mathrm{kg}^{-1}$ (in the range of 6.2-2750), 193 $\mathrm{mg} \mathrm{kg}^{-1}$ (in the range of $1.4-193$ ) and $2820 \mathrm{mg} \mathrm{kg}^{-1}$ (in the range of 1-2820), respectively. They obtained these results during the period from 2006 to 2007 when the battery factory was still in operation. Four years later, after that factory closed, our group collected plant samples from this area for the current study, and the obtained values are given in Table III and Figures 2 and 3. The correlation coefficient between $\mathrm{Pb}$ and histidine concentrations was $r=0.77$ for Eleagnus angustifolia L., $\mathrm{r}=-0.05$ for Vitis vinifera $L$. and $\mathrm{r}=0.44$ for Nerium oleander $L$. Hence, a significant linear correlation of $r=0.77$ was found for Eleagnus angustifolia $L$. .

It has also been reported that metal concentrations in plants change depending on the plant species, polluted source, and the wind direction. Onianwa and Fakayode (27) determined trace metal levels in topsoil and vegetation (Cromonolina odorata, a composite plant) sampled in the vicinity of a lead battery manufacturing plant located in Ibadan, the largest city in Nigeria. They found that the $\mathrm{Pb}$ concentrations in the soil and plants changed significantly depending on wind direction: 2010 and $1350 \mathrm{mg}$ $\mathrm{kg}^{-1}$ from NW, 4100 and $970 \mathrm{mg} \mathrm{kg}^{-1}$ from SW, 950 and $3640 \mathrm{mg} \mathrm{kg}^{-1}$ from $\mathrm{NE}$, and 3010 and $1710 \mathrm{mg} \mathrm{kg}^{-1}$ from $\mathrm{W}$, respectively, while the $\mathrm{Pb}$ concentrations in the plant samples taken from the control site were $10 \mathrm{mg} \mathrm{kg}^{-1}$ (27). They concluded that $\mathrm{Pb}$ levels in plants did not depend on the soil-Pb concentra- 
TABLE III

$\mathrm{Pb}$ and Histidine Concentrations in the Studied Samples ( $\mathrm{mg} \mathrm{kg}^{-1}$ )

\begin{tabular}{|c|c|c|c|c|c|c|}
\hline $\begin{array}{c}\text { Plant } \\
\text { Species }\end{array}$ & $\begin{array}{l}\text { Sampling } \\
\text { Site }\end{array}$ & Histidine & $\mathrm{Pb}$ & $\begin{array}{c}\text { Histidine } \\
\text { Range }\end{array}$ & $\begin{array}{l}\mathrm{Pb} \\
\text { Range }\end{array}$ & $\begin{array}{l}\text { apb Range } \\
2006-2007\end{array}$ \\
\hline \multicolumn{7}{|c|}{ Eleagnus angustifolia L. } \\
\hline & G1 & $23 \pm 2$ & $45 \pm 6$ & $3-23$ & $1-45$ & $6.2-2750$ \\
\hline & G2 & $15 \pm 3$ & $8 \pm 1$ & & & \\
\hline & G3 & $14 \pm 2$ & $38 \pm 4$ & & & \\
\hline & B1 & $12 \pm 2$ & $1.0 \pm 0.1$ & & & \\
\hline & B2 & $11 \pm 2$ & $2.0 \pm 0.2$ & & & \\
\hline & B3 & $8 \pm 1$ & $1.0 \pm 0.1$ & & & \\
\hline & Control & $3.0 \pm 0.3$ & $1.0 \pm 0.1$ & & & \\
\hline \multicolumn{7}{|c|}{ Vitis vinifera $L$. } \\
\hline & G1 & $10 \pm 2$ & $32 \pm 4$ & $2-33$ & $1-32$ & $1.4-193$ \\
\hline & G4 & $33 \pm 6$ & $27 \pm 3$ & & & \\
\hline & G5 & $11 \pm 2$ & $29 \pm 3$ & & & \\
\hline & B2 & $27 \pm 6$ & $2.0 \pm 0.2$ & & & \\
\hline & B3 & $25 \pm 5$ & $1.0 \pm 0.1$ & & & \\
\hline & Control & $2.0 \pm 0.2$ & $1.0 \pm 0.2$ & & & \\
\hline \multicolumn{7}{|c|}{ Nerium oleander $L$. } \\
\hline & G3 & $11 \pm 2$ & $12 \pm 2$ & $3-11$ & $1-53$ & $1-2820$ \\
\hline & G4 & $9 \pm 1$ & $53 \pm 8$ & & & \\
\hline & G6 & $6 \pm 1$ & $5 \pm 1$ & & & \\
\hline & B2 & $8 \pm 1$ & $2.0 \pm 0.2$ & & & \\
\hline & Control & $3.0 \pm 0.3$ & $1.0 \pm 0.1$ & & & \\
\hline \multicolumn{7}{|c|}{ SRM: Bush Branches and Leaves - NCSDC73348 } \\
\hline & Certifiec & & $7.1 \pm 1.1$ & & & \\
\hline & Foun & & $6.8 \pm 1.0$ & & & \\
\hline
\end{tabular}

${ }^{a}$ These values were taken from references 15, 19, 20. tion, but these results were attributed to the wind direction. Furthermore, hyperaccumulation in a number of species appeared to be the result of airborne contamination of the leaf surface, rather than root uptake and translocation.

Boyd (28) reviewed the interaction between heavy metal pollutants and chemical ecology but concluded that communities and ecosystems are difficult to study due to their complexity. However, a complete understanding of metal pollutant effect is important to help limit the harmful effects of anthropogenic heavy metal pollutants on the Earth's biota. Due to the high levels and toxic effects of $\mathrm{Cu}, \mathrm{Ni}, \mathrm{Cd}$, and $\mathrm{Pb}$, numerous studies have been carried out over the past 10 years to determine their concentrations in the environment, food and biological matrices (29-34). But much more research needs to be done.

\section{CONCLUSION}

Lead concentrations of up to 53 $\mathrm{mg} \mathrm{kg}^{-1}$ were found in the leaves of Nerium oleander L. Other plants

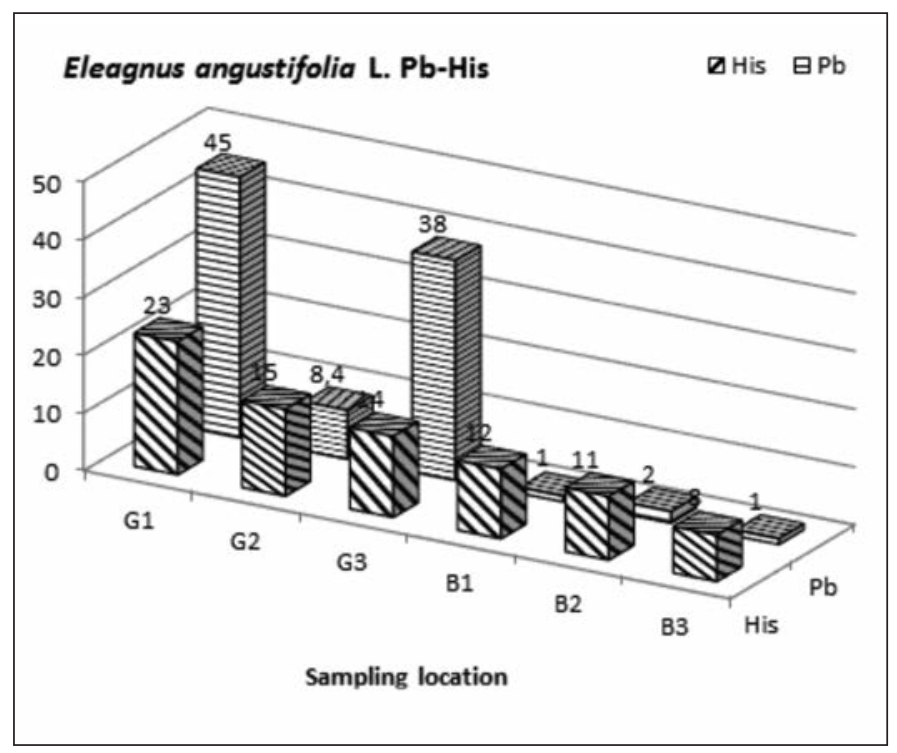

Fig. 2. Comparison of $\mathrm{Pb}$ and histidine levels in E. angustifolia L. depending on sampling location.

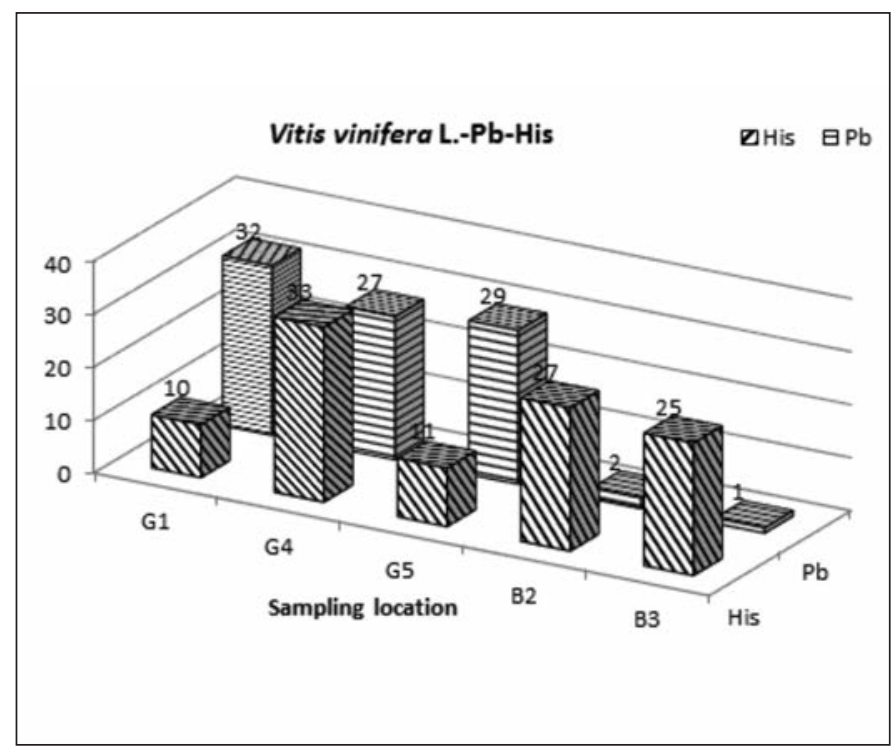

Fig. 3. Comparison of $P b$ and bistidine levels in $V$. vinifera $L$. depending on sampling location. 
such as Eleagnus angustifolia L. and Vitis vinifera $L$. were sampled from a 50-meter distance around an obsolete lead battery manufacturing plant and in other industrial cities in Turkey. The lowest Pb concentration in this plant species was 1.0 $\mathrm{mg} \mathrm{kg}{ }^{-1}$. It was found that the ratio of highest to lowest $\mathrm{Pb}$ concentration for Nerium oleander $L$. was 53-fold, which implies that the leaves of this plant are a potential biomonitor and/or hyperaccumulator. The linear correlation between $\mathrm{Pb}$ and histidine for Eleagnus angustifolia $L$. was found to be $\mathrm{r}=0.77$.

\section{ACKNOWLEDGMENT}

This study was financially supported by the Scientific Investigate Projects of Firat University, Turkey (Project Number: FF.11.19).

Received November 24, 2015.

\section{REFERENCES}

1. W. Mertz, Academic Press, New York, USA, Fifth Ed. (1987).

2. M. Yaman, Curr. Med. Chem. 13(21), 2513 (2006).

3. S.J.S. Flora, J. Environ. Biol. 23 (1), 25 (2002).

4. M.D. Mingorance, S. Rossini Oliva, Environmental Monitoring and Assessment 119, 57 (2006).

5. C.N. Mulligan, R.N. Yong, and B.F. Gibbs, Engineering Geol. 60, 193 (2001).

6. B. Gunawardana, N. Singhal, and A. Johnson, Plant Soil 329, 283 (2010).

7. E. Pilon-Smils and M. Pilau, Critical Reviews in Plant Sciences 21, 439 (2002).

8. M. Yaman, Ekoloji 23(90), 81 (2014).

9. U. Krämer and A.N. Chardonnens, Appl. Microbiol. Biotechnol. 55, 661 (2001).
10. M.J. Haydon and C.S. Cobbett, New Phytol, 174(3), 499 (2007).

11. D. L. Callahan, A. J. M. Baker, S. D. Kolev, and A. G. Wedd, J. Biol. Inorg. Chem. 11, 2 (2006).

12. L. Hunt, C.W.N. Anderson, N. Bruce, A.M. García, et al., Green Processing and Synthesis, 3(1), 3 (2014).

13. J. L. Hall, Journal of Experimental Botany 366, 1 (2002).

14. U. Krämer, J.D. Cotter-Howells, J.M. Charnock, et al., Nature 379, 635 (1996).

15. G. Kaya, N. Okumus, and M. Yaman, Fresenius Environ Bull. 19(4), 669 (2010).

16. G. Kaya and M. Yaman, Trace Elements and Electrolytes 25(3), 156 (2008).

17. G. Kaya and M. Yaman, Talanta 75,1127 (2008).

18. G. Kaya, C. Ozcan, and M. Yaman, Bull. Environ. Contam. Toxicol. 84(2), 191 (2010).

19. G. Kaya and M. Yaman, Spectrosc. Spectral Anal. 32(1), 229 (2012).

20. G. Kaya and M. Yaman, Instrumentation Science \& Technology 40(1), 61 (2012).

21. A. Kabata-Pendias, Trace Elements in Soils and Plants, Fourth Edition, Taylor and Francis Group (2011).

22. S.E. Allen (Eds.), Chemical Analysis of Ecological Materials, Oxford: Blackwell Scientific Publications, UK (1989).

23. R. Bargagli, Plants as Biomonitors, in: Trace Elements in Terrestrial Plants: an Ecophysiological Approach to Biomonitoring and Biorecovery. Springer, BerlinHeidelberg-New York (1998).

24. A. Mulgrew and P.Willeams, Biomononitoring of Air Quality Using Plants, Air hygiene report no:10 Berlin, Germany, WHO CC. 165, (2000).

25. J. Mertens, S. Luyssaert, and K. Verheyen, Environmental Pollution 138, 1 (2005).

26. S. Clemens, M.G. Palmgren, and U. Kramer, Trends Plant Sci. 7, 309 (2002).

\section{Atomic Spectroscopy 1 Vol. 37(4), July/August 2016}

27. P.C. Onianwa and S.O. Fakayode, Environ. Geochem. Health 22, 211 (2000).

28. R.S. Boyd, J. Chem. Ecol. 36(1), 46 (2010).

29. M. Yaman, G. Kaya, and H. Yekeler, World J. Gastroenterology 13(4), 612 (2007).

30. C. Er, BF. Senkal, and M. Yaman, Food Chem. 137(1-4), 55 (2013).

31. OA. Ozen, A. Songur, M. Sarsilmaz, M. Yaman, and I. Kus, J. Trace Elem. Med. Biol. 17(3), 207 (2003).

32. M. Yaman and N. Cokol, At. Spectrosc. 25(4), 185 (2004).

33. M. Yaman and S. Bakirdere, Mikrochim. Acta 141, 47 (2003).

34. I. Ugulu, Appl. Spectrosc. Reviews 50, 113 (2015). 